\title{
Influence of heat treatment on the corrosion behavior of steels exposed to CCS environment
}

\author{
A. Pfennig ${ }^{1}$, P. Wojtas ${ }^{1}$, I. Spengler ${ }^{1}$, B. Linke ${ }^{1}$ \& A. Kranzmann ${ }^{2}$ \\ ${ }^{1} H T W$ University of Applied Sciences, Germany \\ ${ }^{2}$ BAM Federal Institute of Materials Research and Testing, Germany
}

\begin{abstract}
The influence of heat treatment on pit corrosion needs to be considered to guarantee reliability and safety during the injection of compressed emission gasses - mainly containing $\mathrm{CO}_{2}$ - into deep geological layers (CCS-technology, Carbon Capture and Storage). In laboratory experiments different heat treated steels used as injection pipe with $13 \%$ Chromium and $0.46 \%$ Carbon (X46Cr13, $1.4034)$ as well as $0.2 \%$ Carbon $(\mathrm{X} 20 \mathrm{Cr} 13,1.4021)$ were tested. Also $\mathrm{X} 5 \mathrm{CrNiCuNb} 16-4$ (1.4542) was investigated as typical steel used for geothermal pumps. Keeping stable environmental conditions in laboratory experiments the samples were exposed to the distinct synthetic aquifer environment saturated with technical $\mathrm{CO}_{2}$ at a flow rate of $3 \mathrm{l} / \mathrm{h}$ for up to 6 months. Independent of the exposure time the least amount of pits is found on hardened steels with martensitic microstructure where $\mathrm{X} 5 \mathrm{CrNiCuNb} 16-4$ shows fewer pits than $\mathrm{X} 46 \mathrm{Cr} 13$ and $\mathrm{X} 20 \mathrm{Cr} 13$. Regarding steels with similar Cr-content the higher Ccontent in 1.4034 results in fewer pits compared to 1.4021 .
\end{abstract}

Keywords: steel, heat treatment, pit corrosion, $\mathrm{CCS}, \mathrm{CO}_{2}$-injection, $\mathrm{CO}_{2}$-storage.

\section{Introduction}

Engineering a geological on-shore aquifer CCS-site (CCS Carbon Capture and Storage [1-3]) corrosion of the casing and injection pipe steels may become an issue when emission gasses, e.g. from combustion processes of power plants, are compressed into deep geological layers [4-8]. From thermal energy production it is known, that the $\mathrm{CO}_{2}$-corrosion is sensitively dependent on alloy composition, contamination of alloy and media, environmental conditions like temperature, 
488 Energy and Sustainability III

a)
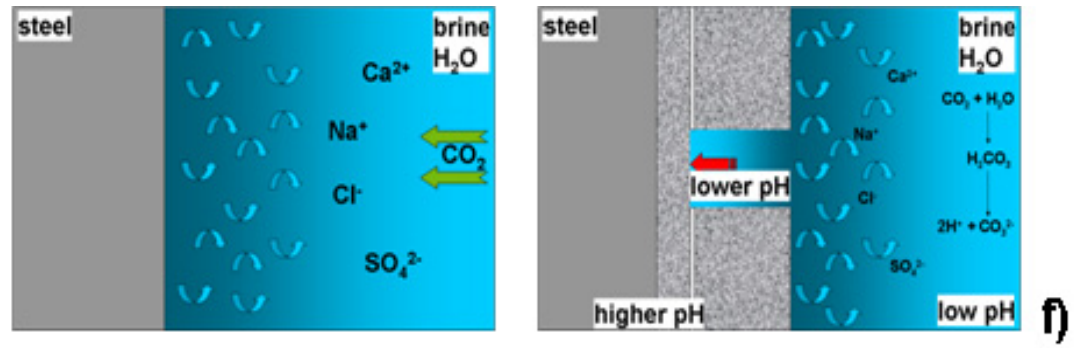

b)
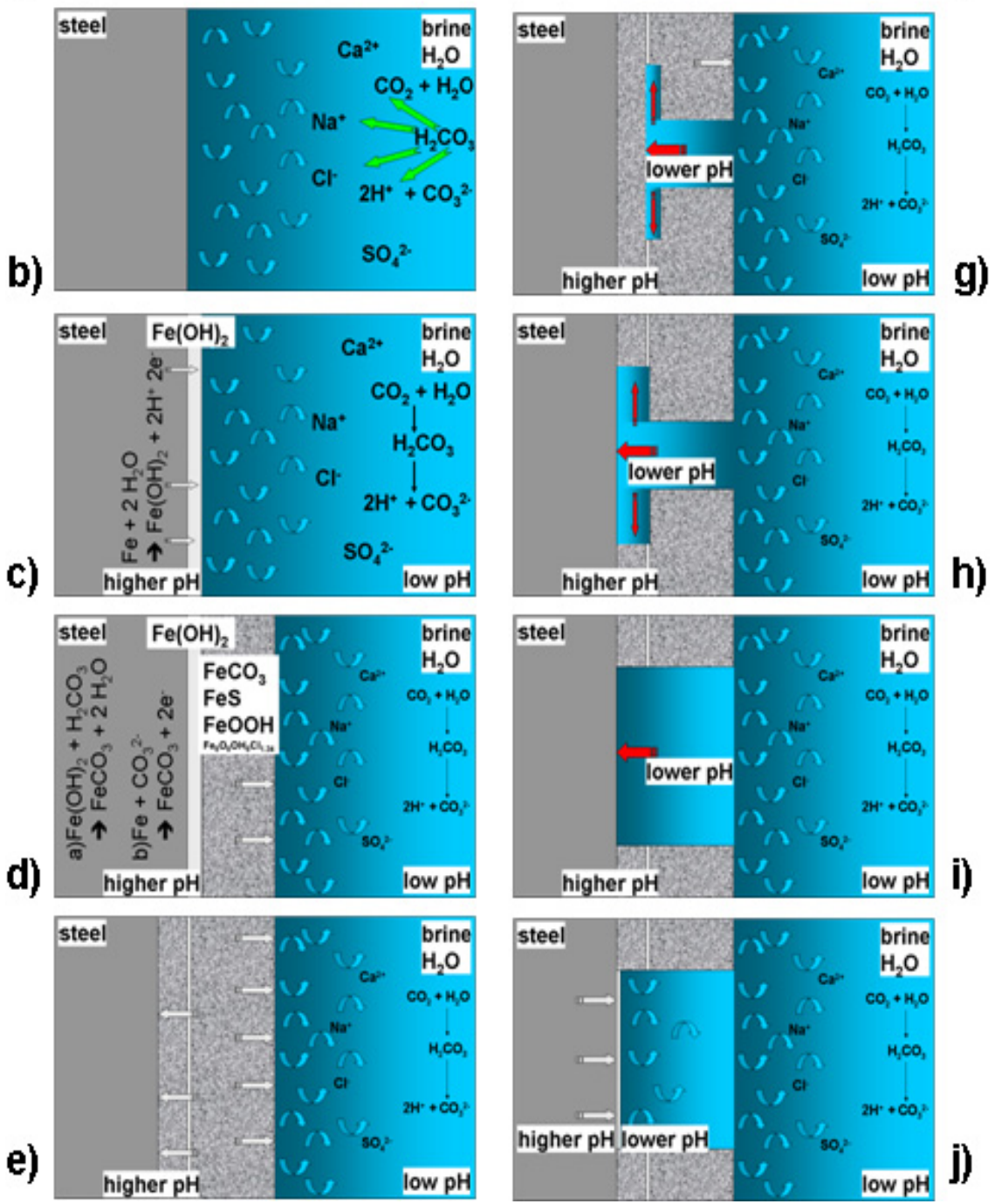

Figure 1: $\quad$ Possible formation mechanism of pits on the pipe steel X46Cr13 related to the galvanic model described by Han et al. [21] and adjusted by Pfennig and Kranzmann [19]. 
$\mathrm{CO}_{2}$ partial pressure, flow conditions and protective corrosion scales [6-16]. Considering different environments, aquifer waters and pressures, the analyzed temperature regime between $40{ }^{\circ} \mathrm{C}$ to $60{ }^{\circ} \mathrm{C}$ is a critical temperature region well known for corrosion processes as shown by Pfennig and Bäßler [17] and Pfennig and Kranzmann $[18,19]$. Here a maximum around $4.7 \mathrm{~mm} / \mathrm{year}$ was found for the pit intrusion depth of $13 \% \mathrm{Cr}$ steel $\mathrm{X} 46 \mathrm{Cr} 13$. Still this may be predicted by the rather conservative Norsok-Model used in the oil and gas industry to calculate surface corrosion rates of carbon steels [20].

Steels exposed to $\mathrm{CO}_{2}$-environment generally precipitate slow growing surface layers mainly comprised of $\mathrm{FeCO}_{3}$ (siderite) $[4,8,21]$. This phase is also found in pits of locally corroded samples $[17,19]$. After the $\mathrm{CO}_{2}$ is dissolved to build a corrosive environment the solubility of $\mathrm{FeCO}_{3}$ in water is low $\left(\mathrm{p}_{\mathrm{Ksp}}=\right.$ 10.54 at $25^{\circ} \mathrm{C}$ ). As a result of the anodic iron dissolution a siderite corrosion layer grows on the alloy surface. These reactions have been described in detail by various authors $[7,17]$ and a precipitation model has been introduced by Han et al. [21], which was adjusted by Pfennig and Kranzmann [19] (figure 1): In the initial stage the steel is exposed to the corrosive environment, the $\mathrm{CO}_{2}$-saturated brine (a), where the carbon dioxide forms carbonic acid in contact with the aquifer water (b). A ferrous hydroxide passivating film can form when its solubility limit is exceeded (c). A first reaction step may be attributed to the formation of $\mathrm{Fe}[\mathrm{II}]$ compounds $\mathrm{Fe}(\mathrm{OH})_{2}[7,25]$, which leads to an increase of the local $\mathrm{pH}$ near the hydroxide film. Consequently a ferrous carbonate film may be formed (d). Then the growth of the corrosion layer will proceed internally and externally depending on the various carbon and oxygen partial pressures (e). Localized corrosion may then start when the ferrous hydroxide film is locally damaged due to mechanical or chemical effects. The highly porous nonprotective ferrous carbonate is then exposed to the brine environment where the $\mathrm{pH}$ is lower. As a result the ferrous carbonate film dissolves and the steel is locally depassivated (f). This is accompanied by corrosion and passive film dissolution in lateral direction $(\mathrm{g}, \mathrm{h})$ followed by the detachment of the carbonate film (i). The removal of the detached film causes the pit to grow wider, because the same steps will occur from the beginning on the newly exposed surface.

This work was carried out to get a better understanding of the influence of the steel heat treatment on the pit corrosion behaviour. Especially the varying microstructures of steels used for $\mathrm{CO}_{2}$-injections into aquifer water reservoirs are of interest to predict their reliability in on-shore CCS sites.

\section{Materials and methods}

Laboratory experiments were carried out to determine the dependence of heat treatment on pit corrosion behaviour. Different steels used as injection pipe with $13 \%$ Chromium and $0.46 \% \mathrm{C}(\mathrm{X} 46 \mathrm{Cr} 13,1.4034)$ as well as $0.2 \%$ Carbon (X20Cr13, 1.4021) were tested. Also X5CrNiCuNb16-4 (1.4542) was investigated as typical steel used for geothermal pumps. The steels were heat treated differently following protocols usual in the field of metallurgy (table 1). 
Table 1: $\quad$ Heat treatment of samples used in exposure experiments.

\begin{tabular}{|c|c|c|c|c|}
\hline material & heat treatment & $\begin{array}{c}\text { temperature } \\
{\left[{ }^{\circ} \mathrm{C}\right]}\end{array}$ & $\begin{array}{l}\text { hold time } \\
\text { [min] }\end{array}$ & $\begin{array}{l}\text { cooling } \\
\text { medium }\end{array}$ \\
\hline \multirow{5}{*}{$\begin{array}{c}\mathrm{X} 20 \mathrm{Cr} 13 \\
1.4021\end{array}$} & notmalizing & 785 & 30 & air \\
\hline & hardering & 1000 & 30 & oil \\
\hline & hardening + tempering 1 & $1000 / 600$ & 30 & oil \\
\hline & hardening + tempering 2 & $1000 / 670$ & 30 & oil \\
\hline & hardening + tempering 3 & $1000 / 755$ & 30 & oil \\
\hline \multirow{5}{*}{$\begin{array}{c}\mathrm{X} 46 \mathrm{Cr} 13 \\
1.4034\end{array}$} & normalizing & 785 & 30 & air \\
\hline & hardenitg & 1000 & 30 & ail \\
\hline & hardening + tempering 1 & $1000 / 650$ & 30 & oil \\
\hline & hardening + tempering 2 & $1000 / 670$ & 30 & oil \\
\hline & hardening + tempering 3 & $1000 / 700$ & 30 & oil \\
\hline \multirow{5}{*}{$\begin{array}{c}\mathrm{x} 5 \mathrm{CrNiCuNb} 16-4 \\
1.4542\end{array}$} & normalizing & 850 & 30 & air \\
\hline & harderitrg & 1040 & 30 & oil \\
\hline & hardening + tempering 1 & $1040 / 550$ & 30 & oil \\
\hline & hardening + tempering 2 & $1040 / 650$ & 30 & oil \\
\hline & hardening + tempering 3 & $1040 / 755$ & 30 & oil \\
\hline
\end{tabular}

Exposure tests in $\mathrm{CO}_{2}$-saturated aquifer brine were carried out using samples of the alloys above with $8 \mathrm{~mm}$ thickness and $20 \mathrm{~mm}$ width and $50 \mathrm{~mm}$ length. A hole of $3.9 \mathrm{~mm}$ diameter was used for sample positioning. The surfaces were activated by grinding with SiC-Paper down to $120 \mu \mathrm{m}$ under water and dipping into acetone for ca. $5 \mathrm{sec}$. Samples of each base metal were positioned within the liquid phase [17-19]. The brine (as known to be similar to the Stuttgart Aquifer [23]: $\mathrm{Ca}^{2+}: 1760 \mathrm{mg} / \mathrm{L}, \mathrm{K}^{2+}: 430 \mathrm{mg} / \mathrm{L}, \mathrm{Mg}^{2+}: 1270 \mathrm{mg} / \mathrm{L}, \mathrm{Na}^{2+}: 90.100$ $\mathrm{mg} / \mathrm{L}, \mathrm{Cl}^{-}: 143.300 \mathrm{mg} / \mathrm{L}_{,} \mathrm{SO}_{4}{ }^{2-}: 3600 \mathrm{mg} / \mathrm{L}, \mathrm{HCO}^{3-}: 40 \mathrm{mg} / \mathrm{L}$ ) was synthesized in a strictly orderly way to avoid precipitation of salts and carbonates. Flow control $(3 \mathrm{NL} / \mathrm{h})$ of the technical $\mathrm{CO}_{2}$ into the brine was done by a capillary meter GDX600_man by QCAL Messtechnik GmbH, Munich. The pH after the experiments was between 5.2 and 5.6. The exposure of the samples between $24 \mathrm{~h}$ and $1500 \mathrm{~h}$ into corrosive CCS environment was disposed in a climate chamber according to the conditions at the geological site at Ketzin/Germany at $60{ }^{\circ} \mathrm{C}$ at ambient pressure - each material in a separated reaction vessel (figure 2). X-ray diffraction was carried out in a URD-6 (Seifert-FPM) with CoK $\alpha$-radiation with an automatic slit adjustment, step 0.03 and count $5 \mathrm{sec}$. Phase analysis was performed by matching peak positions automatically with PDF-2 (2005) powder patterns. Mainly structures that were likely to precipitate from the steels were chosen of the ICSD and refined to fit the raw-data-files using POWDERCELL $2.4[22]$ and AUTOQUAN ${ }^{\circledR}$ by Seifert FPM. 

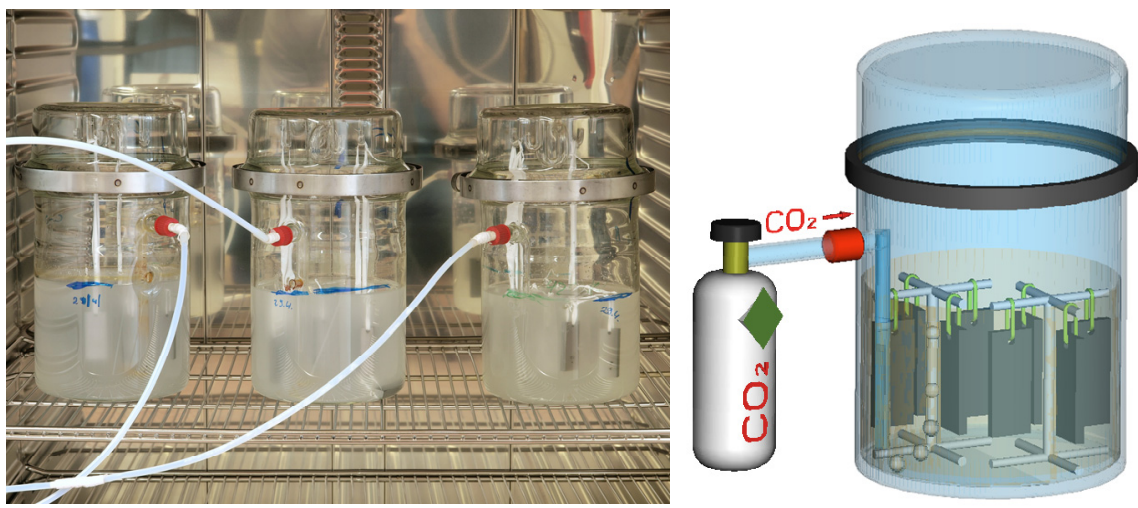

Figure 2: $\quad$ Experimental set up of laboratory corrosion experiment.

Sample surfaces were analyzed with a light optical microscope Axiophot 2 by Zeiss. Here the kinetics was obtained by counting the pits per frame (6 frames per sample, 2 samples per parameter) and giving the average pit number. Pit widths were measured light optically and pit depths were obtained from 3-Dimages. These 3-D-images were realized by the double optical system Microprof TTV by FRT. Mass gain was analyzed according to DIN 50905 part 1-4. After the surface analysis the samples were embedded in a cold resin (Epoxicure, Buehler), cut and wet polished first with SiC-Paper from $180 \mu \mathrm{m}$ to $1200 \mu \mathrm{m}$. The finishing was done with diamond paste $6 \mu \mathrm{m}$ and $1 \mu \mathrm{m}$. Different light optical and electron microscopy techniques were used to investigate the layer structures and morphology of the samples.

\section{Results and discussion}

\subsection{Kinetics}

To evaluate the influence of the heat treatment the samples were examined via light optical methods to predict the amount of counted pits and the pit depths. Kinetics was obtained via weight loss according to DIN 50905 (figure 3) after exposure to the $\mathrm{CO}_{2}$-saturated aquifer water.

With corrosion rates obtained via mass gain method about $0.002 \mathrm{~mm} /$ year the normalized samples show the lowest loss of base material. Samples that were hardened or hardened and tempered corrode around $0.005 \mathrm{~mm} /$ year determined after 1400 hours of exposure time. Therefore hardening and tempering does not influence the corrosion rate significantly. 


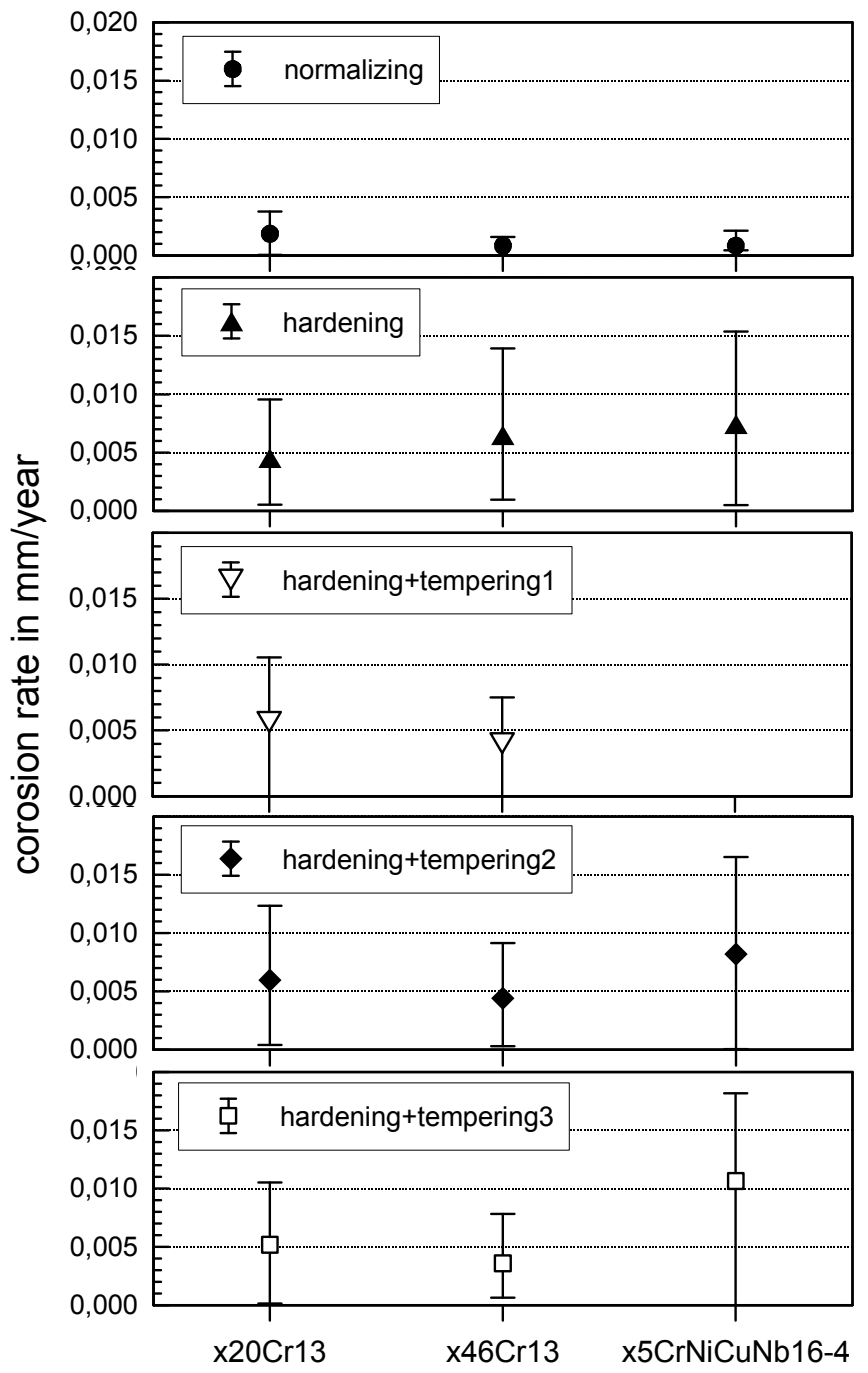

Figure 3: Corrosion rate after 1350 hours of exposure to aquifer brine water at $60{ }^{\circ} \mathrm{C}$ and ambient pressure of $\mathrm{X} 20 \mathrm{Cr} 13, \mathrm{X} 46 \mathrm{Cr} 13$ and $\mathrm{X} 5 \mathrm{CrNiCuNb} 16-4$ differently heat treated prior to exposure.

\subsubsection{Depth of pits}

Pitting (local corrosion) and shallow pit corrosion are observed on all specimens (figure 4).

Optical 3-D-images of a characteristic sample part after descaling are shown in Figure 5 with a typical penetration depth of approximately $18 \mu \mathrm{m}$ into $\mathrm{X} 5 \mathrm{CrNiCuNb} 16-4$. 

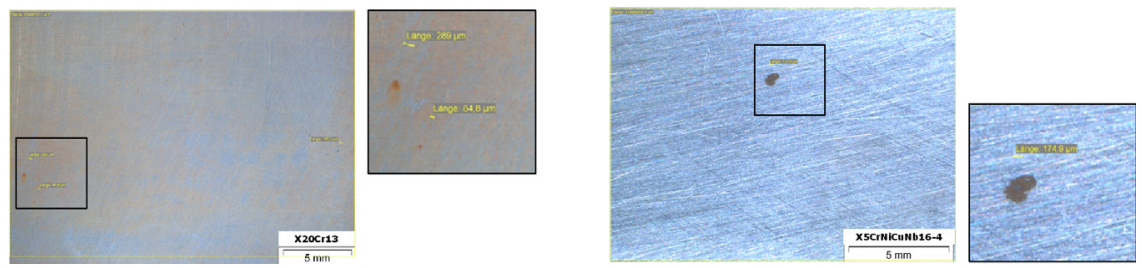

Figure 4: $\quad$ Surfaces with pits of $\mathrm{X} 46 \mathrm{Cr} 13$ (left) and $\mathrm{X} 5 \mathrm{CrNiCuNb} 16-4$ (right).
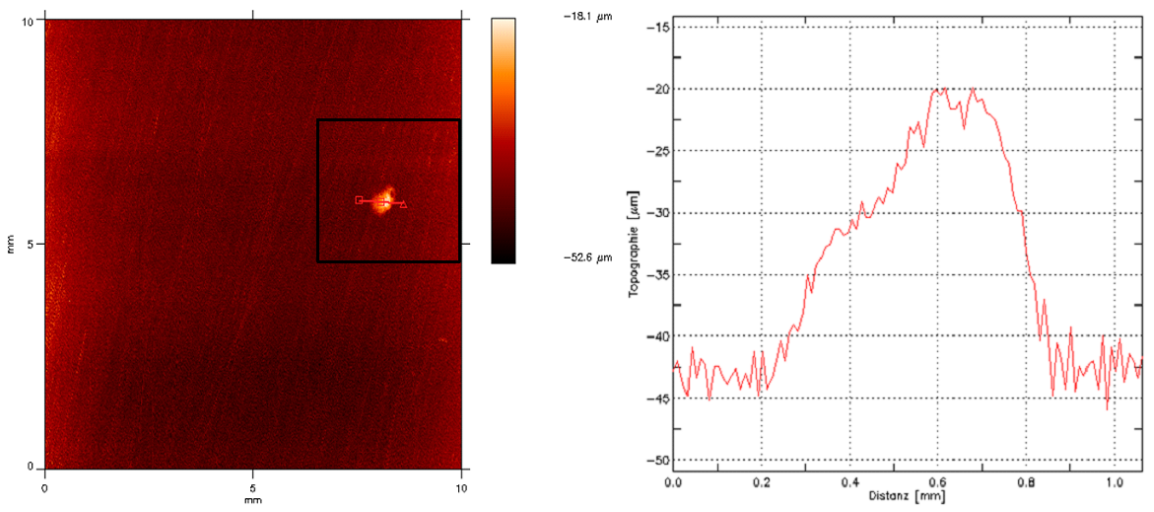

Figure 5: $\quad$ Optical 3D-Surface-Scan (Fa. FRT) of the sample X5CrNiCuNb16$4 \mathrm{kept}$ in the $\mathrm{CO}_{2}$-saturated brine for $14000 \mathrm{~h}$.

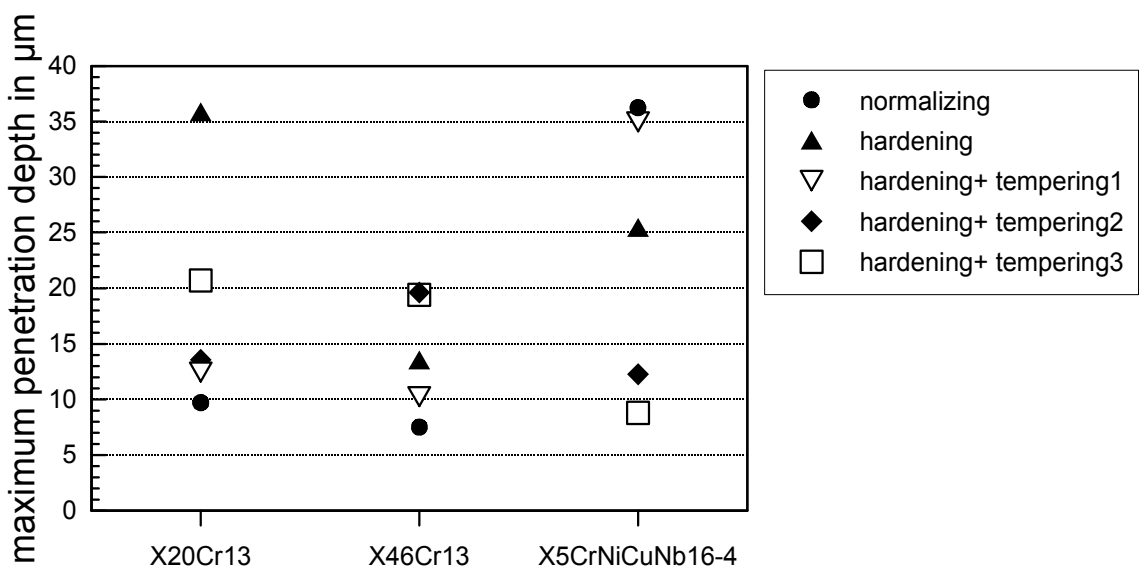

Figure 6: Maximum penetration depth of pits formed on alloys X20Cr13, $\mathrm{X} 46 \mathrm{Cr} 13$ and $\mathrm{X} 5 \mathrm{CrNiCuNb} 16-4$ after exposure to the $\mathrm{CO}_{2}$ saturated brine for 1400 hours. 
The local corrosion shows a maximum intrusion depth about $35 \mu \mathrm{m}$ for $\mathrm{X} 20 \mathrm{Cr} 13$ and $\mathrm{X} 5 \mathrm{CrNiCuNb} 16-4$ after 1400 hours of exposure. Figure 6 compares all measured intrusions depths as a function of heat treatment for the different steels. Overall figure 6 reveals that pit depths measured on X46Cr13 do not penetrate as deep as pits measured on the other steel samples. Still, the heat treatment has little to no influence on the maximum penetration depth. For the $13 \mathrm{Cr}$ steels (X20Cr13 and $\mathrm{X} 46 \mathrm{Cr} 13)$ normalizing and hardening+tempering1 show less intrusion $(8-12 \mu \mathrm{m})$ than the other heat treatments, while hardening+tempering 2 and 3 seem to be best for $\mathrm{X} 5 \mathrm{CrNiCuNb} 16-4(10 \mu \mathrm{m})$.

\subsubsection{Amount of counted pits}

The influence of heat treatment may be also determined by the amount of counted pits (figure 7). The lower amount of pits on X46Cr13 hardened+tempered 3 and $\mathrm{X} 5 \mathrm{CrNiCuNb} 16-4$ hardened+tempered 1 after $800 \mathrm{~h}$ of exposure is due to surface corrosion phenomena, that is that pits consolidate to shallow pit corrosion and are not longer counted as single pits. These surface corrosion products prevent the access of corrosive media to the bulk material. Figure 7 reveals that the heat treatment has no significant influence on the amount of counted pits per unit area, because there is little to no lowest amount of counted pits for one distinct heat treatment. For X20Cr13 and X46Cr13 normalized samples show the lowest amount of pits while X $5 \mathrm{CrNiCuNb} 16-4$ has the most pits per $\mathrm{m}^{2}$. The most pits on $\mathrm{X} 20 \mathrm{Cr} 13$ and $\mathrm{X} 46 \mathrm{Cr} 13$ were counted on samples hardened+tempered 2.

Pit growth cannot be calculated as easily as surface corrosion rates, because of its little predictability. Therefore it is not possible to give corrosion rates and lifetime predictions regarding pit corrosion in CCS technology. Summarizing the kinetic results the heat treatment preferred to obtain the least corrosive attack is normalizing for $\mathrm{X} 20 \mathrm{Cr} 13$ and $\mathrm{X} 46 \mathrm{Cr} 13$. For $\mathrm{X} 5 \mathrm{CrNiCuNb} 16-4$ the combination hardening+tempering 3 should be preferred. Detailed analysis of the different microstructures and different sucseptabilites towards corrosion under CCS environment will be subject to future research.

\subsection{Morphology}

The complicated multi-layered carbonate/oxide structure is described in detail by Pfennig and Bäßler [17]. It reveals siderite $\mathrm{FeCO}_{3}$, goethite $\alpha-\mathrm{FeOOH}$, mackinawite $\mathrm{FeS}$ and akaganeite $\mathrm{Fe}_{8} \mathrm{O}_{8}(\mathrm{OH})_{8} \mathrm{Cl}_{1.34}$ as well as spinel-phases of various compositions. Carbides, such as $\mathrm{Fe}_{3} \mathrm{C}$, were identified within the corrosion layer, similar to the high-temperature corrosion phenomena [24]. The pits are covered with the same precipitates of the corrosion products formed on the surface elsewhere (figure 8). 

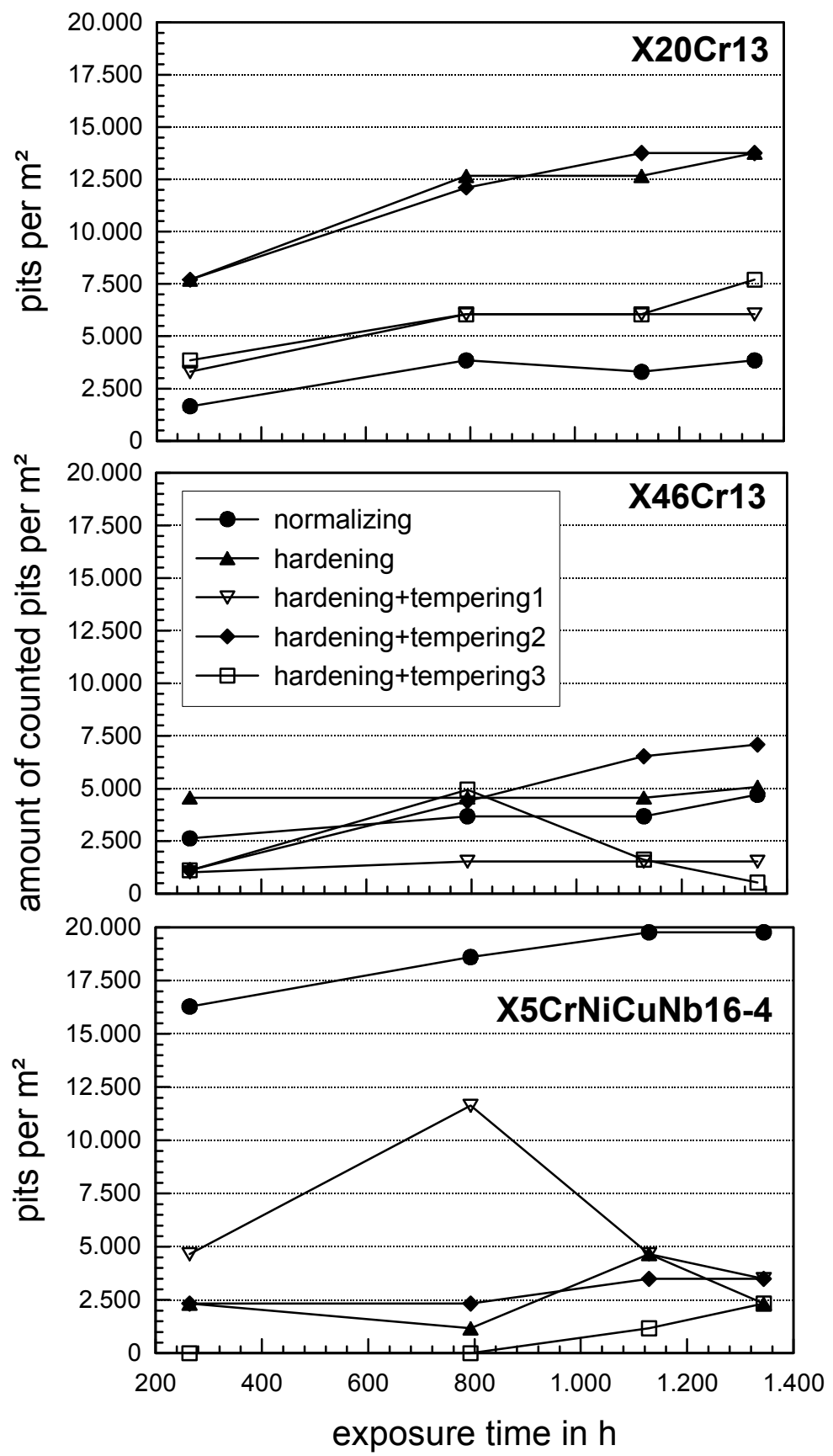

Figure 7: Amount of counted pits of $\mathrm{X} 20 \mathrm{Cr} 13, \mathrm{X} 46 \mathrm{Cr} 13$ and $\mathrm{X} 5 \mathrm{CrNiCuNb} 16-4$ exposed to the brine saturated with $\mathrm{CO}_{2}$ at $60^{\circ} \mathrm{C}$ and ambient pressure. 


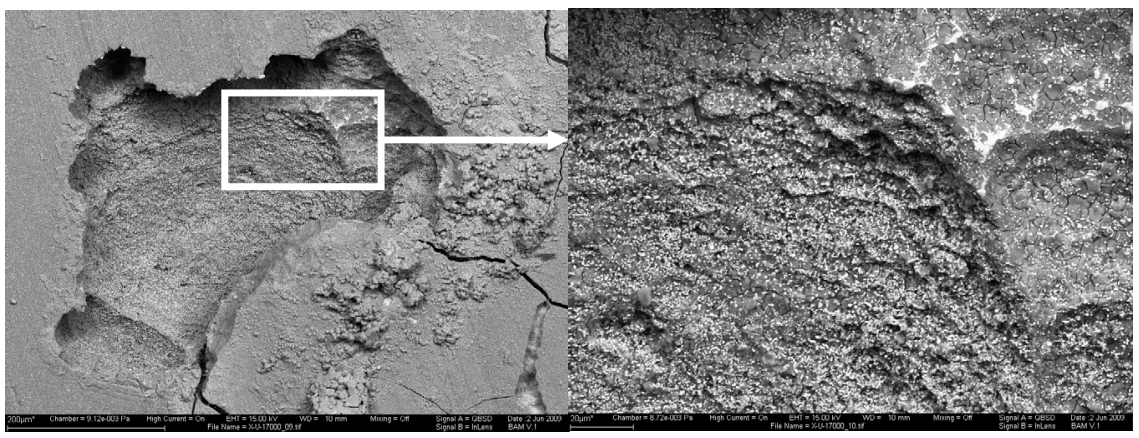

Figure 8: $\quad$ SEM surface images of precipitations on pits of the soft annealed $13 \% \mathrm{Cr}$ steel X46Cr13 after $17520 \mathrm{~h}$.

\section{Conclusion}

During the normal storage procedure the $\mathrm{CO}_{2}$ is supposedly injected in the liquid or supercritical phase. Therefore there is no such pit corrosion expected as from the $\mathrm{CO}_{2}$-saturated brine stated in this paper. However, when there are intermissions of the injection the water level may rise into the injection pipe. This will then lead to the precipitation of corrosion products and formation of pits. Main phase of the continuous scale forming on all three different steels are $\mathrm{FeCO}_{3}$ siderite and goethite $\alpha-\mathrm{FeOOH}$ in 3 steels. The heat treatment preferred to obtain minimal local corrosive attack for $\mathrm{X} 20 \mathrm{Cr} 13$ and $\mathrm{X} 46 \mathrm{Cr} 13$ is normalizing while for $\mathrm{X} 5 \mathrm{CrNiCuNb} 16-4$ the combination hardening+tempering 3 should be considered. For heat treatments regarding hardening and tempering a significant good corrosion resistance cannot be given. Therfore long term exposure experiments and detailed microstructure analysis will be necessary.

\section{Acknowledgements}

This work was supported by the FNK (Fachkonferenz für wissenschaftlichliche Nachwuchskräfte) of the Applied University of Berlin, HTW and by IMPACT (EU-Project EFRE 20072013 2/21). The authors would like to thank M. Blötz, M. Engelke and S. Baack of the HTW for the helpful contribution.

\section{References}

[1] D.C. Thomas, Carbon Dioxide Capture for Storage in Deep Geologic Formations - Results from $\mathrm{CO}_{2}$ Capture Project, Volume 1: Capture and Separation of Carbon Dioxide form Combustion Sources, $\mathrm{CO}_{2}$ Capture Project, Elsevier Ltd UK 2005, ISBN 0080445748

[2] M. van den Broek, R. Hoefnagels, E. Rubin, W. Turkenburg, A. Faaij, Effects of technological learning on future cost and performance of power 
plants with $\mathrm{CO}_{2}$ capture, Progress in Energy and Combustion Science, Paper in Progress (2009) 1-24

[3] GeoForschungszentrum Potsdam, $\mathrm{CO}_{2}$-SINK - drilling project, description of the project PART 1 (2006) 1-39

[4] S. Nešić, "Key issues related to modelling of internal corrosion of oil and gas pipelines - A review", Corrosion Science 49 (2007) 4308-4338

[5] S. Hurter, Impact of Mutual Solubility of $\mathrm{H}_{2} \mathrm{O}$ and $\mathrm{CO}_{2}$ on Injection Operations for Geological Storage of $\mathrm{CO}_{2}$, International Conference of the Properties of Water and Steem ICPWS, Berlin, September 8-11

[6] L. Zhang, J. Yang, J.S. Sun, M. Lu, Effect of pressure on wet $\mathrm{H}_{2} \mathrm{~S} / \mathrm{CO}_{2}$ corrosion of pipeline steel, No. 09565, NACE Corrosion 2008 Conference and Expo, New Orleans, Louisiana, USA, March 16th - 20th, 2008

[7] L.J. Mu, W.Z. Zhao, Investigation on Carbon Dioxide Corrosion Behaviors of $13 \mathrm{Cr}$ Stainless Steel in Simulated Strum Water, Corrosion Science, Manuscript No. CORSCI-D-09-00353 (2009) 1-24

[8] M. Bonis, Weight loss corrosion with H2S: From facts to leading parameters and mechanisms, Paper No. 09564, NACE Corrosion 2008 Conference and Expo, New Orleans, Louisiana, USA, March 16th - 20th, 2008

[9] J. Enerhaug, A study of localized corrosion in super martensitic stainless steel weldments, a thesis submitted to the Norwegian University of Science and Technology (NTNU), Trondheim 2002

[10] V. Neubert, Beanspruchung der Förderrohrtour durch korrosive Gase, VDIBerichte Nr. 2026, 2008

[11] R. Kirchheiner, P. Wölpert, Qualifizierung metallischer Hochleistungswerkstoffe für die Energieumwandlung in geothermischen Prozessen, VDIBerichte Nr. 2026, 2008

[12] H. Zhang, Y.L Zhao, Z.D. Jiang, Effects of temperature on the corrosion behaviour of $13 \mathrm{Cr}$ martensitic stainless steel during exposure to $\mathrm{CO}_{2}$ and $\mathrm{Cl}^{-}$environment, Material Letters 59 (2005) 3370-3374

[13] J.N. Alhajji and M.R. Reda, The effect of alloying elements on the electrochemical corrosion of low residual carbon steels instagnant $\mathrm{CO}_{2}$ saturated brine, Corrosion Science, Vol. 34, No. 11 (1993) 1899-1911

[14] Y.-S. Choi and S. Nešić, Corrosion behaviour of carbon steel in supercritical $\mathrm{CO}_{2}$-water environments, No. 09256, NACE Corrosion 2008 Conference and Expo, New Orleans, Louisiana, USA, March 16th - 20th, 2008

[15] X. Jiang, S. Nešić, F. Huet, The Effect of Electrode Size on Electrochemical Noise Measurements and the Role of Chloride on Localized $\mathrm{CO}_{2}$ Corrosion of Mild Steel, Paper No. 09575, NACE Corrosion 2008 Conference and Expo, New Orleans, Louisiana, USA, March 16th 20th, 2008

[16] Z. Ahmad, I.M. Allam, B.J. Abdul Aleem, Effect of environmental factors on the atmospheric corrosion of mild steel in aggressive sea coastal environment, Anti Corrosion Methods and Materials, 47 (2000) 215-225 
[17] A. Pfennig, R. Bäßler, "Effect of $\mathrm{CO}_{2}$ on the stability of steels with $1 \%$ and $13 \% \mathrm{Cr}$ in saline water" Corrosion Science, Vol. 51, Issue 4 (2009) 931940 ,

[18] A. Pfennig, A. Kranzmann, "Influence of $\mathrm{CO}_{2}$ on the corrosion behaviour of $13 \mathrm{Cr}$ martensitic stainless steel AISI 420 and low-alloyed steel AISI 4140 exposed to saline aquifer water environment", Air Pollution XVII , Volume 123 (2009) 409-418, ISBN: 978-1-84564-195-5, ISSN: 1746-448X

[19] A. Pfennig, A. Kranzmann, The role of pit corrosion in engineering the carbon storage site Ketzin, Germany, WIT Transactions on Ecology and the Environment, Volume 126, (2010) 109-118, ISBN: 978-1-84564-450-5

[20] http://www.standard.no/pronorm-3/data/f/0/01/36/9_10704_0/M506d1r2.pdf, " $\mathrm{CO}_{2}$ corrosion rate calculation model"

[21] J. Han, Y. Yang, S. Nešić, B. N. Brown, Roles of passivation and galvanic effects in localized CO2 corrosion of mild steel, Paper No. 08332, NACE Corrosion 2008, New Orleans, Louisiana, USA, March 16th - 20th, 2008

[22] SW. Kraus and G. Nolze, POWDER CELL - a program for the representation and manipulation of crystal structures and calculation of the resulting X-ray powder patterns, J. Appl. Cryst. (1996), 29, 301-303

[23] A. Förster, B. Norden, K. Zinck-Jørgensen, P. Frykman, J. Kulenkampff, E. Spangenberg, J. Erzinger, M. Zimmer, J. Kopp, G. Borm, C. Juhlin, C. Cosma, S. Hurter, 2006, Baseline characterization of the $\mathrm{CO}_{2} \mathrm{SINK}$ geological storage site at Ketzin, Germany: Environmental Geosciences, V. 13, No. 3 (September 2006), pp. 145-161.

[24] A. Kranzmann, D. Huenert, H. Rooch, I. Urban, W. Schulz, W. Österle, Reactions at the interface between steel and oxide scale in wet $\mathrm{CO}_{2}$ containing atmospheres, NACE Corrosion Conference \& Expo, Atlanta, 2009 